Revista Destaques Acadêmicos, Lajeado, v. 12, n. 1, 2020. ISSN 2176-3070

DOI: http://dx.doi.org/10.22410/issn.2176-3070.v12i1a2020.2504

http://www.univates.br/revistas

\title{
A VISÃO DE FUTURO DOS ESTUDANTES DA UNIVATES EM RELAÇÃO À PREVIDÊNCIA
}

\author{
Samuel Martim Conto ${ }^{1}$, Douglas Ariel Ely ${ }^{2}$
}

Resumo: O tema previdência faz parte da vida dos brasileiros, seja pela Previdência Social, por planos de Previdência Complementar ou por qualquer tipo de investimento que vise garantir um futuro economicamente mais tranquilo. A situação atual (2019) apresenta um panorama na qual o trabalhador não sabe o tempo que terá de contribuir ao INSS, não possui garantia de que receberá os benefícios e caso receber, o valor poderá não ser suficiente para suprir suas necessidades econômicas. Neste contexto, o objetivo deste estudo é entender por meio da pesquisa, como os estudantes da Univates lidam com as questões que dizem respeito à previdência, como por exemplo, a crise da Previdência Social, a adesão de outras formas de investimento e a preocupação com o futuro. A pesquisa foi desenvolvida quanto ao modo de abordagem de forma qualitativa, utilizando-se entrevistas em profundidade com questões que visaram responder aos objetivos propostos. A partir da análise das entrevistas, percebeu-se a importância dada pelos participantes ao hábito de poupar, foi possível ainda entender como cada respondente lida com suas finanças pessoais, além das opiniões sobre a Reforma da Previdência Social e da sua situação atual. Foram analisados aspectos sobre a Previdência Complementar em relação aos motivos de adesão e de não-adesão, além dos perfis de investidor de cada participante, e realizados questionamentos a respeito do planejamento de longo prazo e sobre as expectativas de cada entrevistado perante seu futuro.

Palavras-chave: Previdência social. Previdência Complementar. Investimentos. Visão de futuro.

\section{INTRODUÇÃO}

O termo Previdência Social está sendo visto como sinônimo de preocupação para os brasileiros que ainda não recebem benefícios e se veem sem nenhuma garantia real de que possam se aposentar. Com o passar das décadas, houve uma série de mudanças demográficas no país, como por

1 Professor da Universidade do Vale do Taquari.

2 Graduado em Administração pela Universidade do Vale do Taquari. 
exemplo, o envelhecimento da população. Esses fatores influenciam a situação apresentada pela Previdência Social atualmente (2019), na qual os déficits crescem a cada ano. Em 2016, foi de R \$ 151,9 bilhões, em 2017, foi de R \$182,4 bilhões, e em 2018, foi de R \$ 195,2 bilhões, segundo informações do Regime Geral da Previdência Social (RGPS, 2019). Permanecendo a situação como está, a Previdência Social poderá se tornar insustentável em alguns anos e a renda oriunda das contribuições poderá não ser suficiente para as necessidades da população.

Os planos de Previdência Complementar, também conhecidos como Previdência Privada, têm apresentado aumento de procura nos últimos anos. Segundo dados da Federação Nacional de Previdência Privada e Vida (FENAPREVI, 2018), em setembro de 2017 haviam 13.704 .032 pessoas com planos de Previdência Privada contratados no país, somando uma contribuição de R \$ 9,58 bilhões. A Previdência Privada é uma capitalização e funciona de maneira parecida com uma aplicação financeira, na qual a pessoa poupa uma quantia para complementar a sua renda no futuro. Quanto antes a pessoa começar a aplicar, maior será sua complementação. Sua adesão é de fácil acesso, pois é um produto securitário, administrado por seguradoras, e oferecido por instituições financeiras.

É nesse contexto que a presente pesquisa avaliou a preocupação dos estudantes em meio ao cenário atual e entendeu suas aflições, ideias e atitudes. Com isso buscou entender como a cultura, o conhecimento acadêmico, as experiências de vida e a educação financeira influenciam esses estudantes, para descobrir se é dada importância ao tema da previdência e compreender como isso é pensado e quais são as efetivas ações realizadas no presente para garantir um futuro financeiramente estável.

Este artigo tem como objetivo compreender a visão dos estudantes da Univates quanto ao futuro em relação à previdência. Seus objetivos específicos são: (1) identificar os fatores que levam ou levariam os estudantes da Univates a optarem pela Previdência Complementar (2) analisar as preferências dos estudantes da Univates em relação às opções de previdência (3) relatar a percepção dos estudantes da Univates sobre o futuro da Previdência Social (4) entender de que maneira os estudantes da Univates lidam com suas finanças pessoais e qual sua visão de futuro.

A pesquisa foi desenvolvida a fim de analisar em profundidade o pensamento dos estudantes em relação à previdência. A aposentadoria faz parte do planejamento de vida de grande parte dos cidadãos, porém o grau de atenção a respeito do tema é variado, por isso se fez necessário interpretar como o público-alvo pensa e quais são ou serão suas atitudes em sua vida financeira. 


\title{
2 FUNDAMENTAÇÃO TEÓRICA
}

Para complementar os conhecimentos sobre o tema estudado, foi realizada a busca de dados secundários, através de bibliografias e textos digitais. O referencial teórico constitui a base do trabalho, apresentando os conceitos e as informações que serviram de auxílio na elaboração da pesquisa.

\subsection{Conceito de previdência}

Na presente pesquisa, toda forma de precaução financeira é considerada como previdência, pois a Previdência Social e a Previdência Complementar não são as únicas formas de se precaver diante do futuro. Apesar de grande parte dos brasileiros serem adeptos aos regimes citados, é possível guardar dinheiro para o futuro de outras formas. Portanto, são considerados previdência, todos os tipos de investimento.

De acordo com Martins, Lazzari e Martins (2006), a palavra previdência é a qualidade do que é previdente. Significa também previsão de futuro e conjectura, ou seja, é a ideia de resguardo patrimonial para o futuro.

Ainda sobre previdência, Póvoas (2007) considera que o homem, em qualquer país do mundo, sofre perante as incertezas em relação ao seu futuro e busca segurança. Por isso, as instituições de seguridade social existem no mundo todo, para suprir essa necessidade de segurança e a exigência dos indivíduos pelo bem-estar.

\subsection{Previdência Social}

O conceito de Previdência Social é apresentado pelo Portal do Ministério da Previdência Social:

\begin{abstract}
A Previdência Social é o seguro social para a pessoa que contribui. É uma instituição pública que tem como objetivo reconhecer e conceder direitos aos seus segurados. A renda transferida pela Previdência Social é utilizada para substituir a renda do trabalhador contribuinte, quando ele perde a capacidade de trabalho, seja pela doença, invalidez, idade avançada, morte e desemprego involuntário, ou mesmo a maternidade e a reclusão (PREVIDÊNCIA SOCIAL, 2019, texto digital).
\end{abstract}

Segundo Paixão (1998), a Previdência Social, por meio da contribuição, tem por finalidade assegurar aos seus beneficiários meios de se manter, nos casos de incapacidade, desemprego involuntário, idade avançada, tempo de serviço, encargos familiares e prisão ou morte daqueles de quem dependiam economicamente.

Os aspectos demográficos demonstram que os brasileiros estão controlando a natalidade devido a fatores como o aumento da violência, o 
aumento do custo de ter filhos, o baixo nível educacional da população e a formação de novas configurações familiares. Tais condições demográficas apresentam reflexos negativos para o regime previdenciário de repartição simples, pois os benefícios dos inativos dependem da contribuição dos ativos e o equilíbrio entre receitas e despesas desse regime é em grande parte influenciado por esses fatores (WEINTRAUB, 2003).

A Reforma da Previdência Social foi aprovada pela Câmara em 2019. O desafio do governo é manter o sistema previdenciário sustentável devido às dificuldades de pagamento dos benefícios que poderiam surgir caso o déficit continue. A cada mês são pagos pelo INSS R \$ 34 bilhões, o que corresponde a aproximadamente 29 milhões de benefícios. As despesas do INSS representam em torno de $8 \%$ do Produto Interno Bruto (PIB) e se nada fosse feito, a estimativa é de que até 2060 elas alcancem cerca de 18\%, inviabilizando o sistema. Os objetivos da Reforma da Previdência Social são garantir a sustentabilidade do sistema e equilibrar os regimes público e privado (PREVIDÊNCIA SOCIAL, 2019).

\subsection{Previdência Complementar}

Durante a vida, as pessoas estão sujeitas a infortúnios, tais como morte prematura, invalidez ou ter que enfrentar a velhice recebendo menos se comparado ao período em que se trabalhava. O sistema público de previdência oferece proteção para essas situações, porém enfrenta dificuldades em suprir as reais necessidades do indivíduo, no que diz respeito a valores financeiros. A Previdência Privada surge para amenizar esses possíveis infortúnios. Se constitui de programas privados de adesão voluntária, com o intuito de reduzir os impactos financeiros negativos, complementando a renda do indivíduo (FENAPREVI, 2018).

Os planos de Previdência Complementar podem ser fechados ou abertos. Um plano fechado tem vínculo direto com uma empresa, privilegiando seus colaboradores, e não pode ser acessado por pessoas que não pertençam a determinada empresa, geralmente é mais vantajoso pois em alguns casos a empresa contribui com algum valor além do que é depositado pelo segurado. Já os planos abertos podem ser aderidos por qualquer pessoa. A Previdência Complementar pode ser pensada como uma poupança forçada, na qual se reserva um valor a cada mês para complementar a renda no momento em que não há mais possibilidade de se obter renda através da força de trabalho.

Os planos de Previdência Complementar são classificados em Vida Gerador de Benefícios Livres (VGBL) e Plano Gerador de Benefícios Livres (PGBL). Ambos os planos consistem em acumulação de recursos para posterior retirada. (SUSEP, 2018). A principal diferença entre os dois planos é a tributação. Em ambos é cobrado Imposto de Renda (IR) no momento da retirada dos valores, porém enquanto que no plano VGBL o Imposto de Renda 
incide somente sobre os rendimentos, no plano PGBL ele incide sobre o valor total a ser retirado. Os participantes do plano PGBL podem deduzir até $12 \%$ da renda bruta anual na declaração de Imposto de Renda, enquanto que os prêmios do plano VGBL não podem ser deduzidos.

\subsection{Outros tipos de investimentos}

Investimento, segundo Bernstein e Damodaran (2000), é quando alguém se abstêm do consumo ou do prazer de consumir algo no presente para desfrutar de mais consumo no futuro. Um bom investidor busca utilizar as probabilidades para calcular os riscos do investimento e considera os efeitos da inflação e assim poderá transformar incerteza em quase certeza.

Investir implica em desistir de bons momentos no presente visando obter melhores no futuro. Um exemplo de investimento é ir à escola ou à universidade, nesse caso o estudante utiliza o tempo em que poderia estar se divertindo ou obtendo renda através de trabalho para se dedicar ao estudo, com isso paga taxas escolares e busca aperfeiçoamento e maior conhecimento para ganhar mais dinheiro quando estiver bem preparado. Porém é difícil mensurar quanto o investimento em educação traz de retorno, pois depende de cada caso, e também é difícil saber por quanto tempo esse investimento produzirá uma boa renda (BERNSTEIN; DAMODARAN, 2000).

Para apresentar o que o investimento em educação pode trazer de retorno financeiro, o Gráfico 1 traz a média desse retorno com base nos dados da população da região do Vale do Taquari, RS, com base nos dados obtidos pela Relação Anual de Informações Sociais (RAIS). 
Gráfico 1 - Remuneração média (em salário mínimos) dos trabalhadores do Vale do Taquari conforme a escolaridade

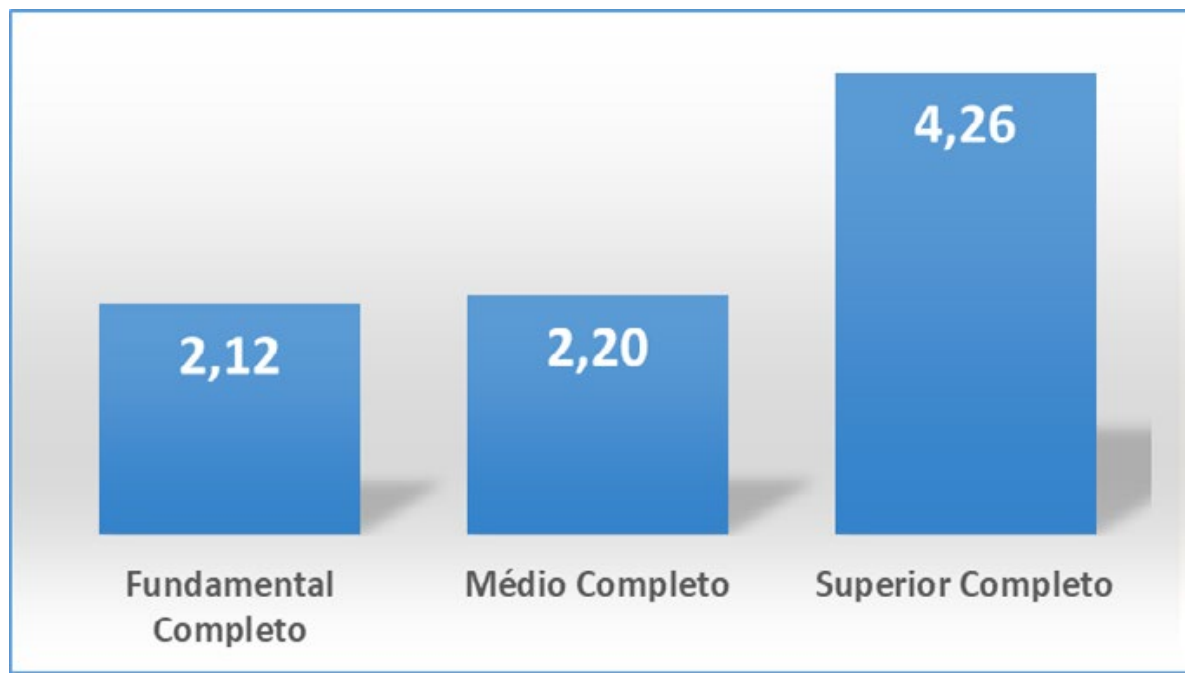

Fonte: Adaptado pelo autor com base em RAIS (2016).

O investimento em educação assim como qualquer outro investimento, envolve certo risco, isso porque o fato de estar graduado não garante um trabalho com boa remuneração. No entanto, o que o Gráfico 1 apresenta é que na média a remuneração de um colaborador que possui ensino superior completo é $93,31 \%$ maior se comparado àquele que somente concluiu o ensino médio (RAIS, 2016).

\subsection{Comparativo entre os tipos de investimento}

Os investidores podem ser classificados em três perfis, que são: conservador, moderado e arrojado. O investidor conservador é aquele que tem por objetivo preservar seu capital e não está disposto a correr riscos, ou até mesmo aquele que não consegue manter um investimento a longo prazo pela necessidade de retirar os recursos. Já o investidor moderado se dispõe a correr alguns riscos a médio prazo, geralmente esse perfil busca diversificar seus investimentos colocando parte dos seus recursos em operações que envolvem risco. Por fim, pode ser considerado um investidor arrojado uma pessoa que tolera altos riscos, que aceita as oscilações do mercado e até certas perdas na busca de retornos positivos no longo prazo (SANTANDER, 2018).

Para fazer uma simples comparação entre alguns dos tipos mais comuns de investimento e entender como se distribui a relação entre o risco e a rentabilidade e também para estar atento a incidência de IR, o Quadro 1 apresenta um comparativo de tipos de investimentos para perfis mais conservadores até os mais arrojados. 
Quadro 1 - Comparativo entre investimentos

\begin{tabular}{|l|l|l|l|}
\hline Tipos de Investimento & Risco & Rentabilidade & Tributação IR \\
\hline Poupança & Muito baixo & Muito baixa & Isenta \\
\hline Aplicação em CDB/RDB & Muito baixo & Baixa & $15 \%$ a $22,5 \%$ \\
\hline Fundos de renda fixa & Baixo & Baixa & $20 \%$ \\
\hline Previdência Privada & Baixo & Média & $10 \%$ a 35\% \\
\hline Imóveis & Baixo & Média & Aproximadamente $15 \%$ \\
\hline Fundos multimercado & Médio & Média & $20 \%$ \\
\hline Dólar & Alto & Média & Aproximadamente $15 \%$ \\
\hline Ações Ibovespa & Alto & Alta & $15 \%$ \\
\hline
\end{tabular}

Fonte: Adaptado pelo autor com base em UDESC (2016).

Conforme é apresentado no Quadro 1, é possível identificar uma linha próxima entre rentabilidade maior e risco maior. Investimentos conservadores como a poupança ou aplicações possuem um risco baixíssimo, porém o retorno é mínimo. O único item do quadro que é classificado como retorno alto são as Ações da Ibovespa, porém seu risco também é classificado como alto, ou seja, são investimentos para perfis arrojados.

\section{PROCEDIMENTOS METODOLÓGICOS}

A presente pesquisa foi caracterizada quanto ao modo de abordagem como qualitativa, porque o objetivo é produzir conhecimento através de uma análise realizada com base nos pensamentos e nas experiências dos entrevistados, que são estudantes da Univates, da geração $Y$, que responderam a questionamentos a partir da aplicação de entrevistas em profundidade.

O termo pesquisa qualitativa, conforme Strauss e Corbin (2008), se refere a pesquisa que produz resultados que não seriam alcançados por procedimentos estatísticos ou meios quantitativos. Ela é realizada sobre a vida das pessoas, sobre suas experiências, comportamentos, emoções e sentimentos. As técnicas qualitativas geralmente são aplicadas através de entrevistas e observações, nas quais são realizadas análises interpretativas.

A caracterização da pesquisa segundo seu objetivo geral é exploratória, devido à necessidade de explorar as informações coletadas através de análise em profundidade na busca de maior conhecimento sobre o tema, e do entendimento a respeito dos pensamentos dos estudantes da Univates em relação aos aspectos do tema previdência, no que diz respeito à importância dada ao tema, as preocupações e as atitudes visando um futuro economicamente estável.

A pesquisa foi desenvolvida através da aplicação de entrevistas semiestruturadas. Foi optado por realizar entrevistas abertas para possibilitar a liberdade de expressão do entrevistado e manter a naturalidade do diálogo, 
no entanto, as perguntas partiram de um roteiro de entrevistas pré-definido de doze questões, que visa responder aos objetivos propostos, e durante a entrevista foi possível acrescentar outros questionamentos para aumentar a qualidade da pesquisa.

Os sujeitos da presente pesquisa, que participaram do trabalho através das respostas às entrevistas em profundidade foram quinze estudantes da Universidade do Vale do Taquari (UNIVATES). Não se optou por delimitar a pesquisa por tipo de curso, sendo assim, foi realizada com estudantes dos cursos de Administração de Empresas, Ciências Biológicas, Ciências Contábeis, Direito, Educação Física, Enfermagem, Engenharia Civil, Gestão de Micro e Pequenas Empresas e Pedagogia. Os entrevistados escolhidos estavam situados na faixa etária que corresponde a geração $Y$, dos 22 aos 37 anos de idade, trabalhar com essa geração proporcionou maior enfoque a pesquisa, pois todos estão presentes no mercado de trabalho.

Foram realizadas quinze entrevistas, nas quais foram selecionados estudantes de alguns cursos da Univates, a seleção ocorreu sem critério estatístico e por conveniência, sendo optado por estudantes que residem nos municípios de Santa Clara do Sul, Cruzeiro do Sul e Lajeado.

Após a coleta e transcrição dos dados obtidos através das entrevistas em profundidade, foi realizada a análise dos dados. Inicialmente foi feita a transcrição na íntegra das gravações, para leitura e compreensão de todos os elementos presentes. Em seguida, a análise ocorreu através do método comparativo sobre as respostas dos entrevistados, citando-se os elementos em comum, os que aparecem com maior frequência e as exceções, através de um profundo estudo sobre cada resposta expressa.

\section{APRESENTAÇÃO E ANÁLISE DAS ENTREVISTAS}

As doze questões que foram apresentadas frente aos participantes durante as entrevistas em profundidade visaram responder aos objetivos propostos, o geral e os específicos, e consequentemente ao problema de pesquisa. Cada um dos subtítulos seguintes traz o conteúdo e as análises correspondentes a um dos objetivos.

\subsection{Visão quanto ao futuro em relação à previdência}

Para atender ao objetivo geral, os participantes responderam questões relacionadas às suas visões de futuro. A primeira pergunta questiona se $o$ estudante possui o costume de poupar. Ao analisar essa questão, verificouse que dois terços dos respondentes afirmaram que possuem o hábito de mensalmente guardar algum valor pensando no futuro. A maior parte dos entrevistados se preocupa em poupar, alguns deles pensam no curto prazo e outros mais a longo prazo, mas foi notório que a maioria considera que poupar 
traz benefícios, como tranquilidade e segurança para os momentos em que surgir alguma emergência.

Dos participantes que se consideram poupadores, se destacam as falas dos entrevistados 5 e 8, que afirmaram respectivamente: "Eu tenho sim o costume de poupar, me considero uma pessoa bem equilibrada nos gastos" e "Eu tenho o costume de poupar sim, aprendi isso de casa, continuo a poupar porque vi que é muito importante e é uma garantia a mais que a gente tem em caso de necessidade".

Um terço dos participantes afirmou que não possui o hábito de guardar dinheiro, e entre as causas que justificam esse fato estão os altos gastos fixos e os aumentos dos preços das necessidades básicas, que faz com que a fatia destinada às contas mensais acabe consumindo a cada mês, uma parte maior do salário. Essa é a realidade que foi citada pelo entrevistado 11, que afirma o seguinte: "Não tenho o costume de poupar porque o salário que eu recebo por mês já vai para contas destinadas como financiamento, luz, água, telefone, internet e o pouco que sobra é utilizado pra lazer. Mas pretendo poupar no futuro".

A pergunta de número dois se refere a como os estudantes da Univates organizam seus gastos. A maneira de organizar as finanças acaba sendo algo muito pessoal, cada entrevistado tem seu próprio método de lidar com elas de acordo com os gastos que considera mais importante ou até mesmo pela forma de agir e controlar. A informação que se extraiu através das respostas é de que cinco respondentes utilizam planilha de Excel e outros dois utilizam-se de caderno de anotações para controlar os gastos, ainda quatro participantes afirmam que se organizam por ordem de prioridade e os outros quatro não chegam a fazer controles, apenas se preocupam para não gastar mais do que recebem.

A utilização de planilha de Excel e caderno de anotações por quase metade dos participantes da pesquisa demonstra que esses estudantes optam por usar ferramentas como facilitador para o controle dos gastos. A utilização da planilha de Excel é representada pela fala do entrevistado 7: "Organizo meus gastos através de uma planilha do Excel, na qual lanço mensalmente minhas receitas e minhas despesas".

Sobre a organização dos gastos por ordem de prioridade, destaca-se a fala do entrevistado 6: "Me organizo para dar preferência às necessidades básicas, alimentação, água, luz, internet e combustível. Quando sobra, então gasto algo com item supérfluos". Esses participantes que se organizam por prioridade não fazem controles financeiros, mas se mostram cientes dos gastos que são mais importantes.

A terceira questão diz respeito quanto ao percentual que cada participante poupa pensando no futuro. E em relação aos dez respondentes que poupam, o percentual varia de $5 \%$ até $60 \%$ dos seus salários por mês. Considerando que todos os respondentes são assalariados, na média, os respondentes poupadores guardam em torno de $30 \%$ do seu salário ao mês. 
Sobre essa questão do percentual do salário que é investido por mês se destaca a fala do entrevistado 6: "Tento poupar de 10\% a 20\% da minha renda mensal, caso algum mês eu não consiga, eu tento compensar nos próximos meses".

A questão número quatro solicitou que os participantes expressassem sua opinião sobre a Previdência Social e a Previdência Privada. Percebeu-se através da realização das entrevistas, uma preocupação muito forte por parte de todos os participantes sobre o futuro da Previdência Social. Ao se referirem a Previdência Social, ela foi citada como uma forma insegura de garantir o futuro, também foram utilizadas as expressões instituição quebrada, instável e incerta. Ainda foram realizados comentários sobre o baixo valor dos benefícios e sobre o medo de não recebê-los. Um terço dos participantes alertou que não se pode depender só do INSS.

Sobre a preocupação em relação ao futuro da Previdência Social, se destaca a fala do entrevistado 14: "Vejo a situação da Previdência Social como crítica, não consigo acreditar em um retorno justo no futuro, indiferente do percentual que é recolhido hoje, não se consegue ter uma certeza de quanto deste valor irá retornar como aposentadoria". O entrevistado citado deixa claro essa questão do sentimento de insegurança em relação ao retorno da Previdência Social. Já sobre as falas que sugerem a não-dependência exclusiva da Previdência Social, destaca-se o que foi dito pelo entrevistado 8: "Minha opinião sobre a Previdência Social e pelo que a gente observa sobre o cenário atual, é que não podemos depender só dela, hoje a gente paga o INSS, mas sem certeza de retorno".

Alguns entrevistados abordaram a ideia de complementar a Previdência Social através de uma adesão a um plano de Previdência Privada, destaca-se a fala do entrevistado 5:

Sobre a Previdência Privada, na minha opinião, ela vai cada vez mais ser o caminho para os jovens que querem ter uma situação mais confortável no futuro, não podemos nos basear só na Previdência Social, o melhor negócio é fazer uma Previdência Privada.

\subsection{Fatores que levam ou levariam a optar pela Previdência Privada}

A questão número cinco se refere exclusivamente à Previdência Privada, o primeiro questionamento foi realizado com a finalidade de descobrir se o participante possui ou não um plano de Previdência Privada, os questionamentos seguintes foram feitos a partir da resposta dessa questão inicial. Dos quinze participantes da pesquisa, seis afirmaram possuir um plano de Previdência Privada, enquanto que nove não possuem, sendo portanto esse tipo de investimento aderido pela minoria do público-alvo, mesmo assim é uma proporção expressiva se considerada a não-obrigatoriedade desse tipo de plano. 
Os participantes que responderam sim ao primeiro questionamento, foram submetidos a outros questionamentos sobre seus planos de Previdência Privada. O primeiro deles diz respeito ao motivo pela qual se optou pelo plano. Uma das razões citadas pelos participantes sobre a adesão do plano é a questão da segurança, já o motivo principal que influenciou a maior parte dos entrevistados adeptos foi o fato da empresa oferecer um plano fechado de Previdência Privada. É o que salienta o entrevistado 13: "Tenho um plano de Previdência Privada, optei pelo plano porque ele é oferecido pela empresa em que trabalho, na qual a empresa deposita uma porcentagem e a outra parte fica por minha conta". Esse tipo de plano costuma ser muito vantajoso, pois todo valor que a empresa deposita entra como benefício para o optante do plano de previdência.

O questionamento seguinte se refere ao tempo que cada entrevistado optante de plano de Previdência Privada pretende manter os aportes. A maior parte dos respondentes considera a aposentadoria como o período ideal para o resgate do valor. Sobre essa questão se destaca a fala do entrevistado 5: "Pretendo mantê-lo até chegar na terceira idade, até não poder mais trabalhar, não quero resgatar logo, quero deixar como um investimento futuro". A resposta do entrevistado citado remete ao objetivo de Previdência Privada, que é longuíssimo prazo, para o futuro.

Por fim, aos entrevistados adeptos da Previdência Privada, se questionou o que pretendem fazer com os recursos no momento em que forem resgatar. A maior parte dos participantes respondeu que pretendem complementar a renda do INSS, também foi dito manter a qualidade de vida que se tem hoje e ter uma vida tranquila no futuro, Para exemplificar, é citada a fala do entrevistado 4: "No dia em que eu me aposentar, não vou mais receber tanto quanto recebo atualmente e esses recursos vão complementar a minha Previdência Social".

Aos que não possuem um plano de Previdência Privada, foi perguntado se já haviam pensado em contratar um plano. Dois terços desses participantes responderam que já haviam tido interesse em fazer uma Previdência Privada. A não-contratação pode ocorrer por alguns motivos como, a falta de clareza sobre o produto, as taxas cobradas pelas Instituições Financeiras e a dificuldade de guardar dinheiro a longo prazo. É interessante a fala do entrevistado 10, que relata dois dos motivos citados: "Eu já tive um plano em uma empresa em que eu trabalhei e na hora do resgate tive vários descontos. Hoje eu não faria por essa questão do produto não ser tão claro e pelos descontos no momento do resgate".

Aos que não possuem Previdência Privada, ainda foi questionado se poupam de outra forma. Desses respondentes, dois terços se dividem entre guardar dinheiro em aplicação ou em poupança. É o que cita o entrevistado 12: "Não tenho Previdência Privada, nunca pensei em fazer mas gostaria de ter, eu poupo, eu destino parte do meu salário pra minha conta poupança do banco". 


\subsection{Preferências em relação às opções de previdência}

Para entender como cada participante age para se precaver diante do futuro, foi realizada a pergunta de número seis, que questiona a maneira na qual os entrevistados organizam seus investimentos. Seis participantes guardam dinheiro somente na poupança, enquanto que outros quatro diversificam os investimentos entre poupança, aplicações, fundos e a Previdência Privada.

Para exemplificar as falas dos participantes que investem exclusivamente em poupança, é citada a fala do entrevistado 2: “Eu organizo meus investimentos através da minha conta poupança, depositando mensalmente o valor que for possivel e controlando meus gastos para não precisar mexer na conta". E em relação àqueles participantes que diversificam seus investimentos, destacam-se as falas dos entrevistados 4: "Eu tenho um valor em fundos de investimento e invisto mensalmente na poupança", e 5: "Eu tenho poupança, aplicação, tenho algo investido em imóveis e na Previdência Privada, e invisto na qualidade de vida, minha e dos meus filhos". Percebe-se a forma bem particular com a qual cada entrevistado lida com seus investimentos, a partir do seu perfil de investidor e dos seus objetivos.

Com a sétima questão se propôs descobrir qual o perfil de investidor de cada participante. Foi solicitado que cada entrevistado indicasse de qual perfil se considera, com base em três tipos de perfis, conservador, moderado e arrojado. Foi considerado como conservador aquele que investe somente em um produto que contém risco muito baixo, moderado como aquele que investe em mais de um produto e arrojado como aquele que investe em produtos que possuem risco alto.

Dos quinze entrevistados, onze se consideram conservadores e quatro se veem como investidores moderados, enquanto que nenhum dos entrevistados se considerou arrojado. Dos participantes de perfil conservador, a maior parte deles afirma que utiliza somente a poupança para guardar dinheiro, assim como cita o entrevistado 9: "Meu perfil é conservador, pela questão de usar a poupança, de só fazer investimentos de renda fixa". O fato da maior parte dos participantes serem conservadores tem relação com o risco de perder dinheiro, assim como se percebe através da fala do entrevistado 3 :

Eu sou conservadora, pois tenho só uma poupança e uma aplicação financeira, porque não tenho tanta renda para investir em algo mais arriscado, pois as chances de perder são grandes e como não tenho uma estabilidade financeira tão grande seria arriscado perder o pouco que tenho. Na poupança tenho segurança que mesmo com rendimentos baixos, o valor não vai diminuir.

Os participantes de perfil moderado, se consideram enquadrados a esse perfil de investimento devido a quantidade de produtos na qual investem, esses participantes intercalam investimentos de várias formas, cada um de maneira distinta. Os produtos investidos pelos moderados são poupança, 
fundos de investimento, aplicações, em imóveis e na Previdência Privada. O que se percebe é que todos os respondentes moderados optam pela opção da poupança em conjunto com outros investimentos, ou seja, não deixam de investir no produto mais tradicional e popular do sistema financeiro. $\mathrm{O}$ perfil de investidor moderado é representado pela fala do entrevistado 14: "Me considero moderada, por guardar dinheiro em três opções diferentes, Previdência Privada, poupança e aplicação".

A pesquisa não identificou nenhum respondente que se considere de perfil arrojado. $\mathrm{Na}$ busca de entender a inexistência desse perfil entre os participantes, destacou-se a fala do entrevistado 4: "Eu me considero moderada porque tenho investimentos diversificados, às vezes em poupança e em fundos, mas não arrojado porque me sinto insegura quanto aos riscos que iria correr". Esse entrevistado citou um dos aspectos mais analisados antes de se investir, o risco. A insegurança perante o risco é o principal motivo que faz com que a quantidade de pessoas de perfil de investimento arrojado seja inferior às pessoas de perfil conservador.

\subsection{Percepção sobre o futuro da Previdência Social}

A pergunta de número oito solicita a opinião dos participantes sobre a Reforma da Previdência Social. O que se obteve através das respostas foram visões bem distintas entre os entrevistados, ficando bem divididas entre os que são a favor e os que são contra a reforma. Os favoráveis à reforma somam um número um pouco maior em relação aos contrários.

Sobre esse ponto de relação entre a necessidade da Reforma e os problemas que a sociedade terá que enfrentar, devido à situação que se apresenta pela Previdência Social, destacou-se a fala do entrevistado 7:

Eu acredito que a Previdência Social chegou a esse ponto em que precisa fazer a reforma, devido aos altos gastos para pagar aposentadorias precoces e desnecessárias, o problema é que quem é prejudicado sempre somos nós trabalhadores, que além de termos que contribuir por bem mais tempo, pagamos cada vez mais impostos.

Em uma linha de pensamento muito próxima, também foram mencionados alguns erros cometidos na Previdência Social, através da fala do entrevistado 5:

Eu acho que a Reforma da Previdência Social já deveria ter sido feita a mais tempo, nós vemos muitos casos de pessoas que recebem benefícios que não seriam necessários, que poderiam muito bem estar trabalhando. É bem normal que a Previdência não consiga suportar sendo que têm mais pessoas recebendo que contribuindo, no cenário atual. 
Em relação aos participantes contrários à Reforma, destaca-se a fala do entrevistado 15, que comenta sobre os prejuízos aos trabalhadores, que podem ocorrer a partir da reforma:

Eu acredito que o trabalhador na maioria das vezes acaba sendo lesado, a Reforma tenta melhorar alguns pontos, mas a idade mínima pra se aposentar vai ficando cada vez mais inalcançável, o que era muito mais fácil de alcançar, acaba ficando mais incerto, nós jovens que estamos começando vemos que esse auxílio fica cada vez mais longe.

Com uma visão parecida sobre o tempo de contribuição dos trabalhadores, porém mencionando também sobre o valor dos benefícios, é citada a fala do entrevistado 3 :

Eu acho que a Reforma da Previdência Social, em geral será ruim para os trabalhadores, pra quem precisa trabalhar por um salário-minimo, pois hoje esse valor é muito baixo para se manter e cada vez mais os benefícios se tornarão mais necessários. Também afeta diretamente as pessoas que trabalham pesado, terão que se judiar por mais tempo.

Nota-se a partir das respostas dos participantes, que a Previdência Social passa uma visão de dúvida sobre o futuro, perante a situação que se apresenta, sendo que as palavras mais usadas para descrever o sentimento em relação à Reforma foram incerteza e insegurança. $\mathrm{O}$ assunto na qual os respondentes mais demonstram preocupação é em relação ao tempo de contribuição dos trabalhadores, que afeta diretamente a todos os contribuintes.

A pergunta de número nove questionou aos participantes sobre a renda do INSS, se esse benefício seria suficiente para garantir suas necessidades no futuro. Todos os quinze entrevistados acreditam que a renda oriunda da Previdência Social não será suficiente para suprir todas as necessidades de suas vidas financeiras no futuro.

Sobre essa preocupação em relação ao valor dos benefícios do INSS, se destaca a fala do entrevistado 6: "Do jeito que as coisas estão, provavelmente não será suficiente viver somente com o INSS. Teremos que poupar agora para que não nos falte depois ou ainda ter outras fontes de renda, senão teremos que continuar trabalhando".

Além da preocupação por parte dos participantes sobre o insuficiência do benefício da Previdência Social perante as necessidades básicas, há também uma incerteza sobre a possibilidade de o INSS não conseguir manter os benefícios no futuro. Essa insegurança é citada pelo entrevistado 10:

Tenho certo receio, nem sei se a gente vai chegar a usufruir desse benefício e se a gente receber, eu sei que existe um teto máximo que é possível receber. Junto com as aplicações que faço hoje acredito que sim, mas somente pelo 
salário do INSS, acredito que se continuarem os aumentos das coisas, vai ser bem complicado.

\subsection{Finanças pessoais e visão de futuro}

A questão de número dez instigou os respondentes a se expressarem sobre a maneira na qual lidam com suas finanças pessoas. Junto com essa pergunta de abrangência mais geral, foi questionado se o entrevistado faz controles de gastos e se estabelece objetivos financeiros.

Para exemplificar algumas diferenças de atitude entre as respostas dos participantes, são citados respectivamente os entrevistados 2 e 4: "Eu tenho sempre em mente o quanto recebo por mês e assim eu calculo o quanto vai sobrar para depositar na poupança e alcançar meu objetivo financeiro. Procuro não deixar nada pendente para o próximo mês e manter um saldo na conta corrente para não ficar negativo" e "Sim, todos os anos eu coloco objetivos e o dinheiro que eu consigo guardar durante o ano eu uso para suprir esses meus objetivos. E eu tenho uma planilha em que eu faço um controle mensal das minhas finanças".

A pergunta de número onze questionou aos entrevistados se eles planejam financeiramente seu futuro. A maior parte dos participantes da pesquisa respondeu que planeja sim seu futuro, entre eles destacou-se a fala do entrevistado 5:

Eu trabalho para estar bem, pra continuar levando uma vida boa, quero trabalhar por bastante tempo ainda e conseguir ajudar meus filhos e planejo o futuro com controle, estou guardando dinheiro para tanto daqui a cinco anos e quando me aposentar, estar bem financeiramente.

Ainda sobre planejamento de longo prazo, destaca-se a fala do entrevistado 3: "Quando for me aposentar, quero ter uma vida financeira muito estável, quero ter dinheiro suficiente para me manter sem sufocos e poder não ter dívidas. Quanto mais se poupa na juventude, melhor para quando for se aposentar".

A questão de número doze traz o conceito da vida na $3^{\mathrm{a}}$ idade. Nesse sentido, os participantes foram desafiados a pensar em como pretendem estar quando forem idosos e citar as atitudes que tomam hoje e que podem refletir nessa fase da vida.

Em relação a esse questionamento, destaca-se a fala do entrevistado 4: "Pretendo estar bem, com uma boa qualidade de vida e bem financeiramente, porque eu pretendo, quando for me aposentar, ter me organizado bem para aproveitar minha vida". Ainda no mesmo contexto, se destaca a fala do entrevistado 8: "Eu pretendo ser uma pessoa equilibrada financeiramente quando eu for idosa, ser independente, não precisar que meus filhos me mantenham, quero ter uma estabilidade financeira, viver tranquila, poder viajar, fazer minhas coisas, pagar meus remédios". 
Para exemplificar a maneira como foi abordado esse tema, é citada a fala do entrevistado 12 , que aborda sua forma de se precaver diante do futuro:

Eu faço exercícios físicos, não fumo, não consumo álcool, que já são formas de ser cuidar para o futuro. Porque ficar velho com muitos problemas iria refletir o que eu fui quando mais nova, então quanto mais tempo de energia eu tiver, será melhor pra mim e vou gastar menos dinheiro com medicamentos, é uma forma de guardar dinheiro e ter mais qualidade de vida.

Destaca-se na fala do entrevistado 12, que menciona outras formas de cuidado, que vão além do costume de poupar, como o cuidado com a saúde, pois um futuro com saúde tende a refletir positivamente na vida financeira.

\subsection{Sugestões a partir dos resultados}

Sugere-se que a educação financeira faça parte da vida das pessoas, uma forma importante de integrar esse tema na sociedade seria através de uma disciplina obrigatória nas escolas para o ensino médio e através de projetos educacionais que abordem a educação financeira. Um exemplo de organização que visa auxiliar a sociedade com foco em educação financeira é o projeto A União Faz a Vida, do Sicredi (2018). O projeto busca parcerias com as prefeituras e as escolas dos municípios participantes e aplica práticas educativas nas salas de aula, buscando estimular as atitudes de cooperação e cidadania entre as pessoas da comunidade.

A Previdência Privada pode ser um produto de investimento vantajoso, se utilizado como forma de complementação de renda no futuro. Pois é preciso que o adepto a esse produto esteja consciente das suas características, os recursos podem ser utilizados a qualquer momento, mas o ideal é que ele seja utilizado no longuíssimo prazo, ou seja, quando não houver mais como gerar renda através do trabalho.

Aos que possuem um perfil de investimento moderado e até arrojado, sugere-se que se opte pela diversificação dos seus investimentos, principalmente sobre aqueles que apresentam maior risco, para que o risco total não se concentre em apenas um produto, além de pesquisar, estudar e avaliar cada tipo de investimento, a fim de reduzir o nível de incerteza, e assim ter mais chances de obter bons retornos.

\section{CONSIDERAÇÕES FINAIS}

Percebeu-se através das entrevistas em profundidade que o públicoalvo se preocupa com tema previdência. Nem todos possuem o hábito de poupar, porém é dada importância ao tema. Os que poupam, agem de acordo com seus próprios perfis de investidor. Sobre a Previdência Social, notou-se que é clara a preocupação quanto a insegurança que o sistema público passa, 
e isso faz com que alguns já estejam buscando formas de complementar renda e a Previdência Privada acaba sendo uma dessa formas, pois mesmo sendo adotada pela minoria dos entrevistados, a pesquisa constatou que ela é vista de forma positiva. Por fim, todos os participantes desejam ter um futuro estável e tranquilo, e se mostram conscientes de que é a preparação atual através do hábito de poupar que poderá proporcionar essa situação favorável no futuro.

Os resultados da pesquisa, mediante a aplicação das entrevistas em profundidade, podem ter sofrido influência de alguma limitações. Esse fato se deve pelo tema da pesquisa ser vinculado às finanças pessoais dos participantes, por se tratar de informações pessoais que podem ter sido consideradas sigilosas e assim omitidas.

Para futuras pesquisas, sugere-se a utilização do tema previdência, porém aplicado em outro público-alvo, Caso algum autor queira usar a base deste trabalho de maneira mais específica, sugere-se que seja abordado o costume de poupar através de uma pesquisa quantitativa ou realizada uma pesquisa qualitativa a respeito da situação atual da Previdência Social sobre o ponto de vista de outro público-alvo.

\section{REFERÊNCIAS}

BERNSTEIN, Peter L.; DAMODARAN, Aswath. Administração de investimentos. Porto Alegre: Bookman, 2000.

FENAPREVI. Federação Nacional de Previdência Privada e Vida. Disponível em: <http:/ / fenseg.org.br/fenaprevi/home.html>. Acesso em 7 mar. 2018.

MARTINS, João Marcos Brito; LAZZARI, Joao Batista; MARTINS, Lidia de Souza. 1000 perguntas de seguros, previdência privada e capitalização. Rio de Janeiro: Forense Universitária, 2006.

PAIXAO, Floriceno. A previdência social em perguntas e respostas. 34. ed. Porto Alegre: Síntese, 1998.

PÓVOAS, Manuel Sebastião Soares. Previdência privada: filosofia, fundamentos técnicos, conceituação jurídica. 2. ed. São Paulo: Quartier Latin do Brasil, 2007.

PREVIDÊNCIA SOCIAL. Ministério da Previdência Social. Disponível em: <http:/ / www.previdencia.gov.br/>. Acesso em 12 dez. 2019.

RAIS. Relação Anual de Informações Sociais. Disponível em: <http:/ / www.rais.gov. br/sitio/index.jsf>. Acesso em: 27 abr. 2018.

RGPS. Regime Geral da Previdência Social. Disponível em: <http:/ / www. previdencia.gov.br/2019/01/previdencia-social-teve-deficit-de-r-1952-bilhoesem-2018/>. Acesso em: 16 dez. 2019. 
SANTANDER. Banco Santander S.A. Disponível em: <https:/ / www.santander.com. br/>. Acesso em: 29 abr. 2018.

SICREDI. Cooperativa de Crédito, Poupança e Investimento. Disponível em: <https:/ / www.sicredi.com.br/>. Acesso em: 14 abr. 2018.

STRAUSS, Anselm; CORBIN, Juliet. Pesquisa qualitativa: técnicas e procedimentos para o desenvolvimento de teoria fundamentada. 2. ed. Porto Alegre: Artmed, 2008.

SUSEP. Superintendência de Seguros Privados. Disponível em: <http:/ / www.susep. gov.br/>. Acesso em: 12 abr. 2018.

UDESC. Universidade do Estado de Santa Catarina. Tributação no resultado dos investimentos e das aplicações no mercado financeiro nacional. 2016. 57 f. Disponível em: <https://www.revistas.udesc.br/index.php/reavi/article/ download/ 8661/6414>. Acesso em: 29 abr. 2018.

WEINTRAUB, Arthur Braganca de Vasconcellos. Previdência privada: atual conjuntura e sua função complementar ao regime geral da previdência social. 2. ed. São Paulo: Juarez de Oliveira, 2003. 